\title{
Effects of pretreatment with reducing sugars or an enzymatic cocktail before extrusion of fava bean on nitrogen metabolism and performance of dairy cows
}

\author{
S. Mendowski, ${ }^{1,2}$ P. Chapoutot, ${ }^{3}$ G. Chesneau, ${ }^{2}$ A. Ferlay, ${ }^{1}$ () F. Enjalbert, ${ }^{4}$ G. Cantalapiedra-Hijar,,${ }^{1}(0)$ \\ A. Germain, ${ }^{2}$ and P. Nozière ${ }^{1 *}$ (1) \\ ${ }^{1}$ Université Clermont Auvergne, INRA, VetAgro Sup, UMR Herbivores, F-63122 Saint-Genès-Champanelle, France \\ ${ }^{2}$ Valorex, La Messayais, F-35210 Combourtillé, France \\ ${ }^{3}$ UMR MoSAR, INRA, AgroParisTech, Université Paris-Saclay, F-75005 Paris, France \\ ${ }^{4}$ GenPhySE, Université de Toulouse, INRA, ENVT, F-31320 Castanet Tolosan, France
}

\begin{abstract}
The aim of this study was to determine the effects of pretreatment with reducing sugars or with an enzymatic cocktail before extrusion of fava bean on intake, milk yield and composition, $\mathrm{N}$ partitioning, and plasma and ruminal parameters. The main hypothesis was that these pretreatment conditions would allow better $\mathrm{N}$ protection in the rumen compared with classic pretreatment before extrusion, thanks to an increase of sugar proportion, either exogenous or endogenous with enzymatic actions. Sixteen Holstein cows were used in a $4 \times 4$ Latin square design experiment. Cow were fed a diet with a 56:44 forage to concentrate ratio and containing $16.2 \%$ of crude protein $(\mathrm{CP}$; dry matter basis). Concentrate consisted of fava bean:linseed blends (90:10\%, raw basis) distributed either raw, extruded after pretreatment without additive, extruded after pretreatment with reducing sugars, or extruded after pretreatment with an enzymatic cocktail. The experimental blends provided $53 \%$ of total $\mathrm{CP}$ in the diet. Intake, milk yield and composition, ruminal $\mathrm{pH}$, volatile fatty acids and ammonia kinetics, apparent total-tract nutrient digestibilities and $\mathrm{N}$ partitioning, Maillard compounds in feed and feces, plasma AA, and ${ }^{15} \mathrm{~N}$ natural enrichment were measured. Data were analyzed using analysis of variance according to the MIXED procedure of SAS (SAS Institute Inc., Cary, NC). Extrusion without additive during pretreatment led to higher contents of Maillard compounds in the blend, a lower enzymatic CP degradability, a numerically lower ammonia content in ruminal fluid, and a trend of higher plasma EAA concentration, all suggesting a decrease in degradability of proteins in the rumen,
\end{abstract}

Received July 18, 2019.

Accepted September 27, 2019.

*Corresponding author: pierre.noziere@inra.fr and a subsequent increase in metabolizable protein supply. Compared with pretreatment without additive, adding reducing sugars or an enzymatic cocktail during pretreatment led to an increase in Maillard compound contents in the extruded blends, and to an increase $(+50 \mathrm{mg} / \mathrm{L})$ in rumen ammonia content. With reducing sugars, digestibility of Ne-carboxymethyl-lysine was numerically lower, and plasma EAA concentration tended to decrease, suggesting an overprotection of proteins in the intestine. With the enzymatic cocktail, plasma EAA concentration was similar than without additive during pretreatment, suggesting a similar metabolizable protein supply with both treatments. Finally, no change in $\mathrm{N}$ partitioning between milk, urine, and feces was observed whatever the diet.

Key words: dairy cow, extrusion, nitrogen, faba bean

\section{INTRODUCTION}

Consumers are increasingly favoring the use of locally produced, non-genetically modified crops with good traceability in animal feeding (Duc et al., 2010; Titze et al., 2019). In Europe, proteaginous seeds could be a good alternative to imported soybean meal, which is nowadays the main protein source in dairy cow feeding. Indeed, proteaginous seeds can be grown in France and Europe, have the capacity to fix $\mathrm{N}$ from the atmosphere (Duc et al., 2010; Magrini et al., 2016), and have a good yield (for example, $3.05 \mathrm{t} / \mathrm{ha}$ for fava bean in 2016 in France, Terres Univia, 2017). Fava bean contains on average $30 \%$ protein (DM basis), which is quite high, and $44 \%$ starch, but its proteins are very degradable in the rumen (close to $80 \%$, INRA-CIRAD-AFZ Tables, 2017), which impairs the nutritive value of this feed for ruminants. It is known that heat processes, for example extrusion, can reduce the rumen degradability of fava bean proteins (Cros et al., 1991; Benchaar et al., 1992) and so improve their nutritive value, but information 
on effects on milk yield and composition are still scarce (Mendowski et al., 2019). Moreover, too high temperatures in the heat process could lead to overprotection of proteins, thus reducing their intestinal digestibility and making them less available for the animals (Mendowski et al., 2019).

In most published papers focused on digestive utilization of extruded seeds by ruminants, extrusion conditions are poorly described, but generally, extrusion of raw seeds is applied without specific treatment during pretreatment. The present study is focused on innovative pretreatment conditions before the process of extrusion, aiming to improve the effect of extrusion on protection of proteins of fava bean seeds, and subsequent utilization by dairy cows.

The hypotheses are that (1) proteins extruded are protected against degradation in the rumen compared with proteins of raw fava bean, and (2) an addition of reducing sugars or an enzymatic cocktail during pretreatment before extrusion improves the protection of proteins. Indeed, reducing sugars may react and form complexes with proteins through Maillard reactions during the heat process (Alamir et al., 2013). In the same way, the enzymatic cocktail may hydrolyze sugars from starch and these sugars are likely to form complexes with proteins.

To validate these hypotheses, an in vivo experiment was conducted to test the effects of extrusion of fava bean without additive versus with reducing sugars versus with an enzymatic cocktail during pretreatment, on protein utilization by dairy cows. The experimental feedstuffs were precisely characterized, and feed intake, nutrient digestibilities, $\mathrm{N}$ partitioning, milk production and composition, and ruminal and plasma parameters were measured.

\section{MATERIALS AND METHODS}

This study was conducted in INRA facilities (Herbipôle, Theix, France), and all procedures involving animals were approved by the Ethics Committee of the Auvergne-Rhône-Alpes region and the French Ministry of Higher Education, Research and Innovation (APAFIS\#7652-2016111015426814 v6).

\section{Animals, Experimental Design, and Diets}

Sixteen multiparous lactating Holstein cows (parity $=2.9 \pm 0.9$ lactations, $\mathrm{BW}=690 \pm 29 \mathrm{~kg}$, DIM $=$ $96 \pm 27 \mathrm{~d}$, mean $\pm \mathrm{SD}$ ), were allocated in 4 balanced groups (4 cows/group) based on DMI, parity, DIM, and milk yield and composition. The 4 groups received successively the 4 treatments according to a $4 \times 4$ Latin square design. Within each group, all 4 cows received simultaneously the same diet and were used to measure feed intake and milk production and composition $(\mathrm{n}=$ 16); 2 of them were used to measure nutrient digestibilities and N partitioning (called "digestibility cows," $\mathrm{n}=8$ ). Moreover, 1 of these 2 cows was fitted with a rumen cannula (outer and inner diameter of 123 and $106 \mathrm{~mm}$, respectively) and used for ruminal trait measurements $(\mathrm{n}=4)$.

There were 4 experimental periods of $28 \mathrm{~d}$, including $22 \mathrm{~d}$ of adaptation to the diet and then $6 \mathrm{~d}$ of measurements. Throughout the trial, intake was measured daily and individually. During the adaptation period, all cows were housed in free stabling and fed ad libitum. During measurements, all cows were fed at $95 \%$ of the ad libitum intake (determined according to the intake measured between d 14 and 22); the 8 "digestibility cows" were housed in individual stalls, while the others stayed in free stabling.

The 4 experimental diets were iso- $\mathrm{CP}$ and iso- $\mathrm{NE}_{\mathrm{L}}$ (unité fourragère lait; UFL) according to INRA, 2018 (Table 1) and contained $56 \%$ forage and $44 \%$ concentrate (DM basis), with more than $350 \mathrm{~g}$ of $\mathrm{NDF} / \mathrm{kg}$ of $\mathrm{DM}$, close to $280 \mathrm{~g}$ of $\mathrm{NDF} / \mathrm{kg}$ of $\mathrm{DM}$ of from forage, and less than $200 \mathrm{~g}$ of degradable starch $/ \mathrm{kg}$ of DM, to prevent ruminal acidosis (INRA, 2018). All diets were based on the same mixture of corn silage, grass silage (direct cut, first growth from permanent grassland, Auvergne), hay (field cut, first growth from permanent grassland, Auvergne), dehydrated beet pulp, and beet molasses. The experimental concentrate consisted of 90 to $10 \%$ blends (raw basis) of fava bean (Vicia faba) and linseed. Linseed was added to benefit from the effects of its high lipid content on the extrusion conditions of fava bean (Mendowski et al., 2019). The blends were distributed either raw (RW), or extruded at an expected output temperature of $140^{\circ} \mathrm{C}$ with different conditions of pretreatment. Pretreatment conditions were either without additive (EXT), with addition of reducing sugars (SUG) or with addition of an enzymatic cocktail (ENZ), as described below. The low level of protein truly digestible in the intestine (PDI) of the RW diet and the increase in PDI level with extruded blends were expected to allow a measurable marginal response of milk protein yield. The chemical compositions of the blends are presented in Table 2. Raw and extruded blends were supplied by Valorex (Valorex S.A., Combourtillé, France). All diets also contained $0.65 \%$ urea to ensure a sufficient level of available $\mathrm{N}$ for rumen microorganisms. Moreover, animals received 85 g/d of MetaSmart Dry (Kemin France, Nantes, France) to ensure a nonlimiting supply of digestible methionine, $200 \mathrm{~g} / \mathrm{d}$ of mineral and vitamin supplement containing 
Table 1. Ingredients, chemical composition, and nutritive values of the diets

\begin{tabular}{|c|c|c|c|c|}
\hline Item & $\mathrm{RW}^{1}$ & $\mathrm{EXT}^{1}$ & $\mathrm{SUG}^{1}$ & $\mathrm{ENZ}^{1}$ \\
\hline \multicolumn{5}{|l|}{$\%$ of $\mathrm{DM}^{2}$} \\
\hline Corn silage & 28.05 & 28.05 & 28.05 & 28.05 \\
\hline Grass silage & 13.0 & 13.0 & 13.0 & 13.0 \\
\hline Hay & 15.0 & 15.0 & 15.0 & 15.0 \\
\hline Dehydrated beet pulp & 9.0 & 9.0 & 9.0 & 9.0 \\
\hline Beet molasses & 4.3 & 4.3 & 4.3 & 4.3 \\
\hline Fava bean:linseed $(90: 10 \%)$ & 30.0 & 30.0 & 30.0 & 30.0 \\
\hline Urea & 0.65 & 0.65 & 0.65 & 0.65 \\
\hline \multicolumn{5}{|l|}{ Measured chemical composition } \\
\hline $\mathrm{CP}, \mathrm{g} / \mathrm{kg}$ of $\mathrm{DM}$ & 169 & 174 & 171 & 173 \\
\hline NDF, g/kg of DM & 356 & 354 & 352 & 353 \\
\hline Starch, g/kg of DM & 132 & 174 & 184 & 174 \\
\hline $\mathrm{CML}^{3} \mathrm{~g} / \mathrm{kg}$ of DM & 0.025 & 0.032 & 0.036 & 0.036 \\
\hline Lysine, $\mathrm{g} / \mathrm{kg}$ of DM & 8.04 & 7.73 & 6.11 & 7.58 \\
\hline \multicolumn{5}{|l|}{ Nutritive value according to INRA $2018^{4}$} \\
\hline $\mathrm{PDI},{ }^{5} \mathrm{~g} / \mathrm{kg}$ of DM & 78 & 98 & 97 & 96 \\
\hline $\mathrm{RPB},{ }^{6} \mathrm{~g} / \mathrm{kg}$ of $\mathrm{DM}$ & 39 & 25 & 24 & 26 \\
\hline PDIA, ${ }^{7} \mathrm{~g} / \mathrm{kg}$ of DM & 25 & 47 & 46 & 45 \\
\hline $\mathrm{NE}_{\mathrm{L}}, \mathrm{UFL}^{8} / \mathrm{kg}$ of $\mathrm{DM}$ & 0.95 & 0.94 & 0.94 & 0.94 \\
\hline Rumen degradable starch, $\mathrm{g} / \mathrm{kg}$ of DM & 131 & 117 & 123 & 116 \\
\hline LysDi, ${ }^{9} \%$ of PDI & 7.3 & 7.2 & 7.2 & 7.2 \\
\hline MetDi, ${ }^{10} \%$ of PDI & 3.29 & 2.73 & 2.75 & 2.77 \\
\hline \multicolumn{5}{|c|}{$\begin{array}{l}{ }^{1} \mathrm{RW}=\text { raw fava bean:linseed blend }(90: 10 \mathrm{raw} \text { basis }) ; \mathrm{EXT}=\text { extruded at } 140^{\circ} \mathrm{C} ; \mathrm{SUG}=\text { extruded at } 140^{\circ} \\
\text { after pretreatment with reducing sugars; ENZ }=\text { extruded at } 140^{\circ} \mathrm{C} \text { after pretreatment with an enzymat } \\
\text { cocktail. }\end{array}$} \\
\hline \multicolumn{5}{|c|}{$\begin{array}{l}{ }^{2} \mathrm{All} \text { animals received in addition } 85 \mathrm{~g} / \mathrm{d} \text { of MetaSmart Dry (Kemin France, Nantes, France), } 200 \mathrm{~g} / \mathrm{d} \text { of miner } \\
\text { and vitamin supplement (containing } 4.5 \% \mathrm{P}, 20 \% \mathrm{Ca}, 4.5 \% \mathrm{Mg} \text {, and } 5 \% \mathrm{Na} \text { ), and } 200 \mathrm{~g} / \mathrm{d} \text { of sodium bicarbo } \\
\text { ate. }\end{array}$} \\
\hline \multicolumn{5}{|c|}{${ }^{3} \mathrm{CML}=\mathrm{N} \varepsilon$-carboxymethyl-lysine. } \\
\hline \multicolumn{5}{|c|}{${ }^{4}$ Calculated for a level intake of $3.3 \%(\mathrm{DMI}=22.9 \mathrm{~kg}$ and $\mathrm{BW}=690 \mathrm{~kg})$. } \\
\hline \multicolumn{5}{|c|}{${ }^{5} \mathrm{PDI}=$ protein truly digestible in the intestine. } \\
\hline \multicolumn{5}{|c|}{${ }^{6} \mathrm{RPB}=$ rumen protein balance. } \\
\hline \multicolumn{5}{|c|}{${ }^{7} \mathrm{PDIA}=$ dietary protein truly digestible in the intestine. } \\
\hline \multicolumn{5}{|c|}{${ }^{8} 1 \mathrm{UFL}=1,760 \mathrm{kcal}$ of $\mathrm{NE}_{\mathrm{L}}$} \\
\hline \multicolumn{5}{|c|}{${ }^{9} \mathrm{LysDi}=$ lysine truly digestible in the intestine } \\
\hline
\end{tabular}

$4.5 \% \mathrm{P}, 20 \% \mathrm{Ca}, 4.5 \% \mathrm{Mg}$, and $5 \% \mathrm{Na}$ (Galaphos Midi Duo, CCPA, Janzé, France), and $200 \mathrm{~g} / \mathrm{d}$ of sodium bicarbonate (BicarZ, Solvay, Brussels, Belgium).

Forages and concentrate were distributed twice a day, $60 \%$ at $0900 \mathrm{~h}$, and $40 \%$ at $1600 \mathrm{~h}$. Water and a salt block were available ad libitum throughout the experiment. Animals were milked daily at 0730 and 1530 $\mathrm{h}$, in the milking parlor, except for the 8 "digestibility cows" that were milked in individual stalls between $\mathrm{d}$ 23 and 28.

\section{Extrusion Conditions}

Before extrusion treatments, blends underwent a pretreatment, which consisted of grinding followed by thermal preconditioning (Table 3 ) at $60^{\circ} \mathrm{C}$ (EXT and

Table 2. Chemical composition of the fava bean:linseed blends

\begin{tabular}{lcccc}
\hline & \multicolumn{4}{c}{ Fava bean:linseed $(90: 10)$ blend } \\
\cline { 2 - 5 } & Raw & $\begin{array}{c}\text { Extruded at } \\
140^{\circ} \text { without } \\
\text { additive }\end{array}$ & $\begin{array}{c}\text { Extruded at } \\
140^{\circ} \text { with } \\
\text { sugars }\end{array}$ & $\begin{array}{c}\text { Extruded at } \\
140^{\circ} \mathrm{C} \text { with } \\
\text { enzymes }\end{array}$ \\
Item & 959 & 955 & 956 & 956 \\
$\mathrm{OM}, \mathrm{g} / \mathrm{kg}$ of DM & 299 & 314 & 304 & 311 \\
$\mathrm{CP}, \mathrm{g} / \mathrm{kg}$ of DM & 151 & 145 & 136 & 139 \\
$\mathrm{NDF}, \mathrm{g} / \mathrm{kg}$ of DM & 96 & 103 & 331 & 99 \\
$\mathrm{ADF}, \mathrm{g} / \mathrm{kg}$ of DM & 327 & 300 & & 297 \\
Starch, g/kg of DM & & & & \\
\hline
\end{tabular}


SUG) or $68^{\circ} \mathrm{C}$ (ENZ). For ENZ, the pretreatment time was twice as long as for EXT and SUG. During the pretreatment, reducing sugars (SUG) or an enzymatic cocktail (ENZ) was added to the blends at a level of 2.5 and $0.07 \%$ raw basis, respectively. To keep the activity of the enzymes, $8 \%$ of water was added for ENZ. The reducing sugars were mainly composed of glucose, and the enzymatic cocktail was composed of one-third of gluco-amylase and two-thirds of endo-amylase. The activities of enzymes was 300 amyloglucosidase unit/ $\mathrm{mL}$ for gluco-amylases and $480 \mathrm{~kg}$ novo unit/g for endo-amylases. Extrusion of blends took place in single screw extruders. The increase in temperature within the extruders occurred by self-heating as a result of the applied compression and shear forces, without any external thermal energy supply. Based on an analysis of the literature, in vitro and in situ experiments on the blends (Chapoutot et al., 2016, 2018, and unpublished results by P. Chapoutot and O. Dhumez, UMR MoSAR, INRA, AgroParisTech, Université Paris-Saclay, Paris, France), and in vivo results (Mendowski et al., 2019), the target temperature of $140^{\circ} \mathrm{C}$ was previously shown to decrease the ruminal effective degradability of $\mathrm{N}$ without impairing its intestinal digestibility.

In spite of the difference in water addition, the enforced mechanical constraints (compression and shearing) were the same for the 3 blends to reach the desired temperatures: the length to diameter ratio of the extruders was the same for the extrusion of all blends. Indeed, the resistance to advancement by the extruder screw and to the flow through the die was similar for the 3 blends, as described by the applied intensity (around $70 \%$ of the extruder potential).
Temperatures obtained are shown for the last 3 sections in the extruders: $\mathrm{N}-2, \mathrm{~N}-1$, and $\mathrm{N}$ represent antepenultimate, penultimate, and last sections, respectively. Compared with the target temperatures $\left(140^{\circ} \mathrm{C}\right)$, the temperatures reached with the extruder settings were a little bit lower than expected in the N-2 and $\mathrm{N}$ sections, but close to what was expected in the $\mathrm{N}-1$ section $\left(134,142\right.$, and $138^{\circ} \mathrm{C}$ for the blends used in EXT, SUG, and ENZ, respectively). Temperature was slightly higher for blends with sugars than for other extruded blends, in the last 3 sections of the extruder.

\section{Measurements and Sampling}

Feed Intake and $B W$. Intake was measured daily and individually by weighing the offered and the refusals. Indeed, each cow was equipped with an electronic collar that guaranteed access to its own trough only. The DM content of each feedstuff was determined 3 times per week between $\mathrm{d} 1$ and 21, and daily between d 22 and 28, on a sample placed for $24 \mathrm{~h}$ in a ventilated oven at $103^{\circ} \mathrm{C}$. At the same time, a 200-g sample of each feedstuff was collected, pooled over the period at room temperature (except for silages, which were stored at $-20^{\circ} \mathrm{C}$ ), and then oven-dried at $60^{\circ} \mathrm{C}$ for 72 $\mathrm{h}$ before being ground through a 1-mm sieve for subsequent chemical analyses. Every day between d 22 and 28 , the same sampling as for the offered feedstuff was done for the refusals: $10 \%$ of the refusals were collected for the chemical analyses if daily fresh refusals were greater than $1 \mathrm{~kg}$, and the DM content was determined.

Cows were weighed daily at the exit of the milking parlor. The 8 "digestibility cows" were thus weighed

Table 3. Incoming and outgoing parameters of extruders

\begin{tabular}{|c|c|c|c|}
\hline \multirow[b]{2}{*}{ Item } & \multicolumn{3}{|c|}{ Fava bean:linseed (90:10) blend } \\
\hline & $\begin{array}{l}\text { Extruded at } \\
140^{\circ} \text { without } \\
\text { additive }\end{array}$ & $\begin{array}{l}\text { Extruded at } \\
140^{\circ} \text { with } \\
\text { sugars }\end{array}$ & $\begin{array}{l}\text { Extruded at } \\
140^{\circ} \mathrm{C} \text { with } \\
\text { enzymes }\end{array}$ \\
\hline \multicolumn{4}{|l|}{ Pretreatment condition } \\
\hline Duration, $\mathrm{h}$ & 13 & 12 & 20 \\
\hline Temperature, ${ }^{\circ} \mathrm{C}$ & 60 & 60 & 68 \\
\hline Water added, \% & 0 & 0 & 8 \\
\hline \multicolumn{4}{|l|}{ Incoming parameter } \\
\hline $\mathrm{Le} / \mathrm{D}$ ratio $^{1}$ & 8.1 & 8.1 & 8.1 \\
\hline Intensity, $\%$ of extruder potential & 70 & 73 & 70 \\
\hline \multicolumn{4}{|l|}{ Outgoing parameter } \\
\hline \multicolumn{4}{|l|}{ Blend temperature, ${ }^{2}{ }^{\circ} \mathrm{C}$} \\
\hline N-2 & 121 & 125 & 120 \\
\hline $\mathrm{N}-1$ & 134 & 142 & 138 \\
\hline $\mathrm{N}$ & 125 & 132 & 127 \\
\hline Mechanical power, $\mathrm{kW}$ & 78.8 & 82.0 & 78.6 \\
\hline Mechanical energy index, Wh/kg & 56.4 & 55.1 & 44.7 \\
\hline
\end{tabular}


only between d 1 and 20. Body condition score was determined at the beginning of the trial and at the end of each period, according to a 0-5 scale (Bazin, 1984).

Total-Tract Digestibility and $N$ Partitioning. From d 22 to 28 , feces and urine of the 8 "digestibility cows" were collected separately and totally, using in a bin placed behind each cow for the feces and a pouch glued around the vulva of each cow and connected by a flexible pipe to a $30-\mathrm{L}$ flask for urine collection. This flask contained at least $500 \mathrm{~mL}$ of $30 \%$ sulfuric acid to acidify the urine to a $\mathrm{pH}$ less than 4 . Sampling took place every day at $0830 \mathrm{~h}$ and consisted of taking $0.5 \%$ of the total homogenized amount of feces and urine. Samples were immediately pooled per period and frozen at $-20^{\circ} \mathrm{C}$ (Mendowski et al., 2019). The DM of feces was determined by oven drying at $103^{\circ} \mathrm{C}$ for $24 \mathrm{~h}$. Thawed feces samples were either oven-dried for $72 \mathrm{~h}$ at $60^{\circ} \mathrm{C}$, then ground through a $1-\mathrm{mm}$ sieve for NDF, $\mathrm{ADF}$, starch, and ash determination, or lyophilized and ground through a 1-mm sieve for $\mathrm{N}$ assays and determination of Maillard compounds.

Rumen Fermentation Traits. On d 24 and 27, $500 \mathrm{~mL}$ of ruminal fluid was collected just before, and $1,2.5,5$, and $8 \mathrm{~h}$ after the morning meal through the ruminal cannula of the 4 cannulated cows by suction using a hose. Each ruminal liquid sample was filtered using a $250-\mu \mathrm{m}$ nylon pore cloth and then the $\mathrm{pH}$ was measured with a pH meter (WTW PH 538, Inlab Expert 51343100 electrode, Mettler-Toledo, Greifensee, Switzerland). Then, samples were preserved as described in Mendowski et al. (2019), stored at $-20^{\circ} \mathrm{C}$, and used to determine ammonia and VFA concentrations.

Milk Yield and Composition. At every milking, milk production was recorded. For the 4 experimental periods, on d 24, 26, and 27, milk samples from both morning and evening milkings were stored in bronopol at $+4^{\circ} \mathrm{C}$ before analysis of fat, protein, lactose, and urea contents. On d 27, a 60-mL sample of morning milking (frozen at $-20^{\circ} \mathrm{C}$ ) was used to determine the respective proportions of casein versus noncasein $\mathrm{N}$.

Blood Samples. Blood samples were taken from the caudal vein before the morning meal on $\mathrm{d} 27$ of each experimental period in vacutainers with $\mathrm{K}_{3}$ EDTA anticoagulant. For the 8 "digestibility cows," an additional sample was taken with vacutainer with heparin lithium anticoagulant (ref. 455036 for $\mathrm{K}_{3}$ EDTA and 455084 for heparin lithium, Greiner, Kremsmünster, Austria). All collected blood samples were immediately placed in ice before centrifugation at $3,500 \times g$ for $15 \mathrm{~min}$ at $4^{\circ} \mathrm{C}$, then plasma was aliquoted and stored at $-20^{\circ} \mathrm{C}$ ( $\mathrm{K}_{3}$ EDTA anticoagulant) for plasma urea determination, or at $-80^{\circ} \mathrm{C}$ (heparin lithium anticoagulant) for plasma AA profile, taurine, methionine sulfoxide, and ${ }^{15} \mathrm{~N}$ natural abundance analysis.

\section{Chemical Analyses}

For each ingredient of offered diets, refusal and fecal samples, N (Dumas method, norm ISO 16634-1, 2008, using a Rapid N Cube, Elementar Analysensystem GmbH, Hanau, Germany), NDF, ADF (Van Soest et al., 1991), starch (enzymatic method ISO-15914; ISO, 2004), and ash (overnight at $550^{\circ} \mathrm{C}$ ) contents were determined. The enzymatic CP degradability (ED1) of the 4 blends was measured according to Aufrère et al. (1989, 1991). Furosine (early Maillard compound), acrylamide, Ne-carboxymethyl-lysine (CML) (terminal Maillard compounds) and total lysine contents were measured in blends, and CML and total lysine contents were measured in feces according to NiquetLéridon and Tessier (2011). Nitrogen in thawed urine was measured by the Dumas method (using the same device and the same method as for solid samples) by pipetting $300 \mu \mathrm{L}$ on silica (to absorb the liquid) into a N-free tin capsule. For ruminal VFA analysis, samples of the $2 \mathrm{~d}$ of measurement were pooled per cow and per sampling time for each period, and were assayed by GC using crotonic acid as an internal standard (Morgavi et al., 2003). Ammonia was determined by spectrophotometry (Weatherburn, 1967) using a Boehringer Mannheim (Mannheim, Germany) Urea/ Ammonia (Ref. 10542946035) kit (wavelength of 340 $\mathrm{nm}$ ). Milk fat, protein, lactose, and urea contents were measured by the laboratory LIAL (Aurillac, France) with an infrared method. Moreover, morning milk of $\mathrm{d}$ 27 , total $\mathrm{N}$, as well as soluble $\mathrm{N}$ following the precipitation of casein, were determined by the Kjeldahl method (norm ISO 8968-1, LIAL), and milk casein $\mathrm{N}$ was calculated as milk total $\mathrm{N}$ minus soluble N. Plasma urea was measured by photometry using an Arena 20XT device (Thermo Fisher Scientific, Waltham, MA) with a urea kit (ref. 981820 Thermo Fisher Diagnostics SAS, Dardilly, France). Freeze-dried plasma proteins and finely ground feed samples were weighed in tin capsules and analyzed for $\mathrm{N}$ stable isotope composition $\left(\delta^{15} \mathbf{N}\right.$; ${ }^{15} \mathrm{~N} /{ }^{14} \mathrm{~N}$ ratio deviation from the international standard [atmospheric $\mathrm{N}_{2}$ ]) by using an isotope-ratio mass spectrometer (Isoprime, VG Instruments, Manchester, UK) coupled to an elemental analyzer (EA Isoprime, VG Instruments). Glutamic acid was used as internal standard and included in triplicate every 5 samples to correct for possible variations in the raw values determined by the mass spectrometer. Typical replicate measurement errors for these reference materials were $\pm 0.1 \%$; results are expressed using the delta notation. Plasma AA and methionine sulfoxide were assayed by tandem mass spectrometry by Biocrates Life Sciences AG (Innsbruck, Austria) using the Absolute IDQ p180 kit (Biocrates Life Sciences AG). 


\section{Calculations and Statistical Analyses}

The net energy (UFL) and MP (PDI) values of the diets (Table 1) were calculated according to INRA (2018) using the Systool Web application (www.systool .fr; Chapoutot et al., 2015) with a feeding level of 3.2 $\mathrm{kg}$ of DM/100 kg of BW and $44 \%$ of concentrate in the diet, and according to the measured chemical composition of each feedstuff. For calculation of feedstuff PDI values, the effective degradability of $\mathrm{N}\left(\mathbf{E D} \_\mathbf{N}\right)$ of blends was derived from their measured ED1 (ED_N = $85,64,64$, and $66 \%$ for blends used in RW, EXT, SUG, and ENZ, respectively), and the true intestinal digestibility (dr) of their rumen undegraded protein was derived from INRA tabulated values [i.e., $89 \%$ for the raw blend, and $97 \%$ for the 3 extruded blends (INRA, 2018)]. For the other feedstuffs, both ED_N and dr were derived from their chemical composition, according to INRA (2018). Assuming $95 \%$ of protein $\mathrm{N}$ in total $\mathrm{N}, \mathrm{N}$ in milk was calculated as [(milk yield $\times$ milk protein content)/6.38]/0.95 described by DePeters and Cant (1992) and Spanghero and Kowalski (1997). Nitrogen balance was calculated as the difference between $\mathrm{N}$ intake and $\mathrm{N}$ recovered in urine, feces, and milk. The efficiency of metabolizable proteins (PDI efficiency) was calculated as the ratio between protein synthesis and available PDI, according to INRA (2018): protein synthesis accounts for milk + endogenous fecal + scurf + body retention, and available PDI accounts for PDI intake - endogenous urinary proteins (Sauvant et al., 2018). The isotopic discrimination between animal proteins and the diet $\left(\Delta^{15} \mathrm{~N}_{\text {animal-diet }}\right.$ in $\%$ ) was calculated for each animal as the $\delta^{15} \mathrm{~N}$ in plasma proteins minus $\delta^{15} \mathrm{~N}$ of its diet; the latter was calculated as the average $\delta^{15} \mathrm{~N}$ of each ingredient in the diet weighted by the percentage of $\mathrm{N}$ coming from this ingredient.

Data were analyzed according to ANOVA with the MIXED SAS procedure (version 9.4, 2004; SAS Institute Inc., Cary, NC). For each variable, the statistical unit was the mean per diet per cow. Periods $\left(\mathrm{P}_{i}\right.$, with $i=1$ to 4 ) and treatments ( $\operatorname{Trt}_{j}$, with $j=1$ to 4 , RW, EXT, SUG, ENZ) were included in the model as fixed effects, and cows as random effect $\left(\mathrm{C}_{k}\right.$, with $k=1$ to 16 ), with the following model (where $\mu$ is the overall mean and $\varepsilon_{i j k}$ is the error):

$$
\mathrm{Y}_{i j k}=\mu+\mathrm{P}_{i}+\operatorname{Trt}_{j}+\mathrm{C}_{k}+\varepsilon_{i j k} .
$$

The REPEATED statement (with autoregression as covariance structure) was used for kinetics in ruminal fluid to take into account repeated measures on the same cow and at different times $\left(\mathrm{T}_{l}\right.$, with $l=0,1,2.5$, 5 , and $8 \mathrm{~h})$ with $($ Trt $\times \mathrm{T})$ as a fixed effect added to the model:

$$
\mathrm{Y}_{i j k}=\mu+\mathrm{P}_{i}+\operatorname{Trt}_{j}+\mathrm{C}_{k}+\mathrm{T}_{l}+(\operatorname{Trt} \times \mathrm{T})_{j l}+\varepsilon_{i j k}
$$

The differences were considered significant below the threshold $P$-value of 0.05 and a trend was considered at $0.05<P<0.10$. When a significant $P$-value was obtained, means were pairwise compared thanks to $t$ tests using the PDIFF option of SAS.

In addition, analyses of orthogonal contrasts were performed to determine the effects of extrusion (RW vs. [EXT, SUG, ENZ]), and the effects of additives during pretreatment (EXT vs. [SUG, ENZ]). Effects of contrasts are systematically presented in the tables, but were taken into account only when $P$ for the Trt effect was $<0.10$.

\section{RESULTS}

\section{Enzymatic CP Degradability of Blends and Maillard Compound Contents of Feedstuffs}

Extrusion reduced ED1 of blends, from 81.8 to $41.5 \%$, on average (Table 4). The ED1 of blends used in EXT and SUG was very similar (38.7 and 39.8\%, respectively), but was slightly higher for the blend used in ENZ (46.0\%). Acrylamide content was under the limit of detection in all blends except in the blend used in SUG. Extrusion increased the content of CML in blends, especially in the blends used in SUG and ENZ. Total lysine was lower in the blend used in SUG than in the other blends, either raw or extruded. Furosine was higher in extruded blends, in particular in the blend used in SUG, and to a lesser extent in the blend used in ENZ.

Total diet (including fava bean blend) contained $0.025,0.032,0.036$, and $0.036 \mathrm{~g}$ of $\mathrm{CML} / \mathrm{kg}$ of $\mathrm{DM}$ and $8.04,7.73,6.11$, and $7.58 \mathrm{~g}$ of lysine/ $\mathrm{kg}$ of DM for RW, EXT, SUG, and ENZ, respectively (Table 1).

\section{Feed Intake, BW, BCS, Milk Yield and Composition}

No significant effect of treatments was observed on DMI, BW, and BCS on milk yield and FCM, on milk protein concentration and yield, on $\mathrm{N}$ in milk/ $\mathrm{N}$ intake ratio, milk soluble $\mathrm{CP}$, or on milk casein/milk $\mathrm{CP}$ ratio (Table 5). Live BW only slightly increased between the beginning and the end of the experiment (data not shown), averaging $+87 \mathrm{~g} / \mathrm{d}(\mathrm{SEM}=38, P=0.038$ for the $t$-test).

Compared with RW diet, extrusion led to higher milk lactose $(P=0.027)$ and lower milk fat $(P=0.002)$ concentrations. Among extruded treatments, milk fat yield was higher $(P=0.049)$ and milk urea was lower $(P<0.001)$ with additives during pretreatment $(\mathrm{SUG}$ 
Table 4. Enzymatic CP degradability and Maillard compound contents in raw and extruded fava bean blends

\begin{tabular}{|c|c|c|c|c|}
\hline \multirow[b]{2}{*}{ Item } & \multicolumn{4}{|c|}{ Fava bean:linseed (90:10) blend } \\
\hline & Raw & $\begin{array}{l}\text { Extruded at } \\
140^{\circ} \text { without } \\
\text { additive }\end{array}$ & $\begin{array}{l}\text { Extruded at } \\
140^{\circ} \text { with } \\
\text { sugars }\end{array}$ & $\begin{array}{l}\text { Extruded at } \\
140^{\circ} \mathrm{C} \text { with } \\
\text { enzymes }\end{array}$ \\
\hline $\begin{array}{l}\text { ED1, }{ }^{1} \% \\
\text { Maillard compound }\end{array}$ & 81.8 & 38.7 & 39.8 & 46.0 \\
\hline Furosine, $\mathrm{g} / \mathrm{kg}$ of DM & 0.055 & 0.128 & 1.917 & 0.563 \\
\hline $\mathrm{CML},{ }^{2} \mathrm{~g} / \mathrm{kg}$ of $\mathrm{DM}$ & 0.011 & 0.035 & 0.049 & 0.048 \\
\hline Lysine, $\mathrm{g} / \mathrm{kg}$ of DM & 21.0 & 20.0 & 14.6 & 19.5 \\
\hline Acrylamide, $\mathrm{g} / \mathrm{kg}$ of $\mathrm{DM}$ & $<32 \times 10^{-63}$ & $<32 \times 10^{-63}$ & $50.5 \times 10^{-6}$ & $<32 \times 10^{-63}$ \\
\hline
\end{tabular}

${ }^{1} \mathrm{ED} 1$ = enzymatic CP degradability (Aufrère et al., 1989, 1991).

${ }^{2} \mathrm{CML}=\mathrm{N} \varepsilon$-carboxymethyl-lysine.

${ }^{3}$ Limit of detection.

and ENZ), and milk fat concentration was higher with $\operatorname{ENZ}(P=0.002)$.

The net energy balance tended to be higher with EXT than with the other treatments $(P=0.092)$. The PDI use efficiency was lower with extruded treatments $(P<0.001)$, in particular with EXT $(P=0.015)$.

\section{N Partitioning}

Treatment had no significant effect on $\mathrm{N}$ partitioning (Table 6). However, $\mathrm{N}$ balance was higher with extruded diets (averaging $83.5 \mathrm{~g} / \mathrm{d}$ ) than with the RW $\operatorname{diet}(48.8 \mathrm{~g} / \mathrm{d}, P=0.003)$.

\section{Apparent Total-Tract Digestibility and Maillard Compounds in Feces}

No significant effect of treatments was observed on the apparent digestibility of $\mathrm{OM}, \mathrm{N}, \mathrm{NDF}$ ADF, and starch (Table 7).

The apparent digestibility of CML was higher with diets containing extruded blends ( $71 \%$ on average) than

Table 5. Effect of protein source on feed intake, BW, BCS, and milk yield and composition $\left(\mathrm{n}_{\text {cows }}=16\right)$

\begin{tabular}{|c|c|c|c|c|c|c|c|c|}
\hline \multirow[b]{2}{*}{ Item } & \multicolumn{4}{|c|}{ Diet $^{1}$} & \multirow[b]{2}{*}{$\mathrm{SE}$} & \multirow{2}{*}{$\begin{array}{c}P \text {-value } \\
\text { Treatment }\end{array}$} & \multicolumn{2}{|c|}{$P$-value (Contrast) } \\
\hline & $\mathrm{RW}$ & EXT & SUG & ENZ & & & Extrusion & Additives \\
\hline DMI, $\mathrm{kg} / \mathrm{d}$ & 22.9 & 23.3 & 22.6 & 22.8 & 0.51 & 0.612 & 0.806 & 0.210 \\
\hline $\mathrm{BW}, \mathrm{kg}$ & 690 & 695 & 693 & 693 & 7.66 & 0.312 & 0.106 & 0.334 \\
\hline $\mathrm{BCS},{ }^{2}$ point & 2.4 & 2.3 & 2.3 & 2.3 & 0.07 & 0.442 & 0.110 & 0.893 \\
\hline Milk yield, kg/d & 31.2 & 31.5 & 31.9 & 32.1 & 0.84 & 0.485 & 0.232 & 0.348 \\
\hline $4 \%$ FCM yield, $\mathrm{kg} / \mathrm{d}$ & 31.1 & 30.6 & 31.2 & 32.0 & 0.92 & 0.210 & 0.779 & 0.092 \\
\hline $\begin{array}{l}\text { Milk lactose concentration, } \\
\mathrm{g} / \mathrm{kg}\end{array}$ & $48.7^{\mathrm{b}}$ & $49.0^{\mathrm{ab}}$ & $48.8^{\mathrm{ab}}$ & $49.3^{\mathrm{a}}$ & 0.35 & 0.042 & 0.027 & 0.914 \\
\hline Milk fat concentration, $\mathrm{g} / \mathrm{kg}$ & $40.7^{\mathrm{a}}$ & $38.3^{\mathrm{b}}$ & $38.5^{\mathrm{b}}$ & $39.9^{\mathrm{a}}$ & 0.99 & 0.002 & 0.002 & 0.136 \\
\hline $\begin{array}{l}\text { Milk protein concentration, } \\
\mathrm{g} / \mathrm{kg}\end{array}$ & 31.0 & 30.8 & 30.6 & 30.8 & 0.39 & 0.393 & 0.198 & 0.472 \\
\hline Milk fat yield, g/d & $1,266^{\mathrm{a}}$ & $1,205^{\mathrm{b}}$ & $1,228^{\mathrm{ab}}$ & $1,275^{\mathrm{a}}$ & 44 & 0.042 & 0.188 & 0.049 \\
\hline Milk protein yield, $\mathrm{g} / \mathrm{d}$ & 968 & 970 & 976 & 986 & 30 & 0.789 & 0.553 & 0.538 \\
\hline Milk soluble CP, g/kg & 7.1 & 7.2 & 7.0 & 6.9 & 0.13 & 0.282 & 0.438 & 0.085 \\
\hline Milk casein/milk CP & 0.782 & 0.779 & 0.784 & 0.787 & 0.004 & 0.445 & 0.825 & 0.145 \\
\hline Milk urea, mg/L & $260^{\mathrm{b}}$ & $287^{\mathrm{a}}$ & $258^{\mathrm{b}}$ & $265^{\mathrm{b}}$ & 9 & 0.004 & 0.134 & $<0.001$ \\
\hline $\mathrm{N}$ in milk/ $\mathrm{N}$ intake, $\mathrm{g} / \mathrm{g}$ & 0.251 & 0.243 & 0.257 & 0.253 & 0.006 & 0.115 & 0.914 & 0.020 \\
\hline Net energy balance, UFL ${ }^{3} / \mathrm{d}$ & $1.68^{\mathrm{AB}}$ & $1.91^{\mathrm{A}}$ & $1.08^{\mathrm{AB}}$ & $1.01^{\mathrm{B}}$ & 0.37 & 0.092 & 0.314 & 0.020 \\
\hline $\mathrm{PDI}^{4}$ use efficiency, $\mathrm{g} / \mathrm{g}$ & $0.85^{\mathrm{a}}$ & $0.66^{\mathrm{c}}$ & $0.68^{\mathrm{b}}$ & $0.68^{\mathrm{b}}$ & 0.009 & $<0.001$ & $<0.001$ & 0.015 \\
\hline
\end{tabular}

${ }^{\mathrm{a}-\mathrm{c}}$ Different lowercase superscripts indicate a significant difference between treatments $(P<0.050)$.

${ }^{\mathrm{A}, \mathrm{B}}$ Different uppercase superscripts indicate a trend between treatments $(P<0.100)$.

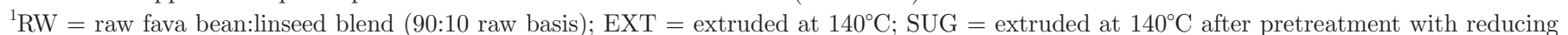
sugars; ENZ $=$ extruded at $140^{\circ} \mathrm{C}$ after pretreatment with an enzymatic cocktail.

${ }^{2} 0-5$ scale (Bazin, 1984).

${ }^{3} 1 \mathrm{UFL}=1,760 \mathrm{kcal}$ of $\mathrm{NE}_{\mathrm{L}}($ INRA, 2018).

${ }^{4} \mathrm{PDI}=$ protein truly digestible in the intestine (INRA, 2018). 
Table 6. Effect of protein source on $\mathrm{N}$ partitioning $\left(\mathrm{n}_{\text {cows }}=8\right)$

\begin{tabular}{|c|c|c|c|c|c|c|c|c|}
\hline Item & \multicolumn{4}{|c|}{ Diet $^{1}$} & $\mathrm{SE}$ & $\frac{P \text {-value }}{\text { Treatment }}$ & \multicolumn{2}{|c|}{$P$-value (Contrast) } \\
\hline DMI, kg/d & 22.9 & 23.7 & 23.5 & 23.1 & 0.5 & 0.543 & 0.303 & 0.430 \\
\hline $\mathrm{N}$ in milk, $\mathrm{g} / \mathrm{d}$ & 154.6 & 155.9 & 160.3 & 158.9 & 6.15 & 0.716 & 0.412 & 0.448 \\
\hline $\mathrm{N}$ urine, $\mathrm{g} / \mathrm{d}$ & 195.7 & 190.0 & 183.8 & 192.6 & 10.17 & 0.796 & 0.463 & 0.879 \\
\hline $\mathrm{N}$ feces, $\mathrm{g} / \mathrm{d}$ & 237.3 & 233.9 & 235.0 & 219.5 & 8.01 & 0.216 & 0.295 & 0.404 \\
\hline
\end{tabular}

${ }^{\mathrm{a}, \mathrm{b}}$ Different superscripts indicate a significant difference between treatments $(P<0.050)$.

${ }^{1} \mathrm{RW}=$ raw fava bean:linseed blend $(90: 10$ raw basis $) ; \mathrm{EXT}=$ extruded at $140^{\circ} \mathrm{C} ; \mathrm{SUG}=$ extruded at $140^{\circ} \mathrm{C}$ after pretreatment with reducing sugars; $\mathrm{ENZ}=$ extruded at $140^{\circ} \mathrm{C}$ after pretreatment with an enzymatic cocktail.

with RW $(64 \%, P<0.001)$. The apparent digestibility of lysine was lower with SUG and ENZ $(52.5 \%$ on average) than with $\operatorname{EXT}(59 \%, P=0.002)$. Consequently, extrusion led to increased CML concentrations in feces $(P=0.011)$, but did not affect fecal lysine content.

\section{Ruminal Parameters}

No significant effect of treatments was observed on mean ruminal $\mathrm{pH}$, total VFA concentration, and butyrate and valerate molar proportions (Table 8).

Extrusion increased acetate $(P=0.003)$, decreased branched-chain VFA $(P<0.001)$, and iso-butyrate $(P$ $<0.001)$ and iso-valerate $(P=0.001)$ molar proportions in the rumen, and tended to decrease the molar proportion of propionate $(P=0.087)$ compared with RW. Ammonia concentration in the rumen was higher with SUG and ENZ $(P=0.006)$ than with EXT, mainly due to the short-term $(1 \mathrm{~h})$ increase of ammonia after the morning meal (Figure 1). Caproate was higher $(P$ $=0.012$ ) with SUG than with other diets.

\section{Plasma Parameters}

Treatments had no significant effect on plasma total AA, His, Lys, Met, Phe, Thr, Trp, NEAA, taurine, or methionine sulfoxide concentrations (Table 9).

Extrusion increased plasma concentrations of $\operatorname{Arg}(P$ $=0.042)$, Leu $(P=0.014)$, Val $(P=0.001)$, and total branched-chain AA (i.e., Leu + Ile + Val, $P=0.007$ ), and tended to increase plasma Ile $(P=0.059)$ and urea $(P=0.071)$ contents, and to decrease $\Delta^{15} \mathrm{~N}_{\text {animal-diet }}(P$ $=0.074)$. Among extruded treatments, plasma urea concentration was lower $(P<0.001)$ and $\Delta^{15} \mathrm{~N}_{\text {animal-diet }}$ was higher $(P<0.001)$ with SUG and ENZ. In addition, Arg, Ile, and Leu contents were higher, and EAA content tended to be higher with EXT and ENZ than with RW and SUG.

Table 7. Effect of protein source on apparent total-tract digestibilities $\left(\mathrm{n}_{\text {cows }}=8\right)$

\begin{tabular}{|c|c|c|c|c|c|c|c|c|}
\hline \multirow[b]{2}{*}{ Item } & \multicolumn{4}{|c|}{ Diet $^{1}$} & \multirow[b]{2}{*}{$\mathrm{SE}$} & \multirow{2}{*}{$\frac{P \text {-value }}{\text { Treatment }}$} & \multicolumn{2}{|c|}{$P$-value (Contrast) } \\
\hline & RW & EXT & SUG & ENZ & & & Extrusion & Additives \\
\hline OM, g/g & 0.70 & 0.70 & 0.70 & 0.70 & 0.006 & 0.937 & 0.858 & 0.728 \\
\hline $\mathrm{N}, \mathrm{g} / \mathrm{g}$ & 0.63 & 0.65 & 0.64 & 0.66 & 0.012 & 0.116 & 0.044 & 0.924 \\
\hline NDF, $g / g$ & 0.57 & 0.54 & 0.54 & 0.55 & 0.012 & 0.184 & 0.042 & 0.779 \\
\hline $\mathrm{ADF}, \mathrm{g} / \mathrm{g}$ & 0.55 & 0.54 & 0.52 & 0.54 & 0.016 & 0.503 & 0.223 & 0.619 \\
\hline Total lysine, $\mathrm{g} / \mathrm{g}$ & $0.57^{\mathrm{a}}$ & $0.59^{\mathrm{a}}$ & $0.50^{\mathrm{b}}$ & $0.55^{\mathrm{a}}$ & 0.016 & 0.002 & 0.176 & 0.002 \\
\hline \multicolumn{9}{|c|}{ Maillard compound content in feces } \\
\hline CML, g/kg of DM & $0.028^{\mathrm{b}}$ & $0.030^{\mathrm{b}}$ & $0.033^{\mathrm{a}}$ & $0.030^{\mathrm{ab}}$ & 0.001 & 0.010 & 0.011 & 0.109 \\
\hline Total lysine, $\mathrm{g} / \mathrm{kg}$ of $\mathrm{DM}$ & 10.62 & 9.69 & 9.61 & 10.44 & 0.541 & 0.180 & 0.127 & 0.479 \\
\hline
\end{tabular}

${ }^{\mathrm{a}-\mathrm{c}}$ Different superscript letters indicate a significant difference between treatments $(P<0.050)$.

${ }^{1} \mathrm{RW}=$ raw fava bean:linseed blend $\left(90: 10\right.$ raw basis); $\mathrm{EXT}=$ extruded at $140^{\circ} \mathrm{C}$; $\mathrm{SUG}=$ extruded at $140^{\circ} \mathrm{C}$ after pretreatment with reducing sugars; $\mathrm{ENZ}=$ extruded at $140^{\circ} \mathrm{C}$ after pretreatment with an enzymatic cocktail.

${ }^{2} \mathrm{CML}=\mathrm{N} \varepsilon$-carboxymethyl-lysine. 
Table 8. Effect of protein source on ruminal parameters $\left(\mathrm{n}_{\text {cows }}=4\right)$

\begin{tabular}{|c|c|c|c|c|c|c|c|c|}
\hline Item & \multicolumn{4}{|c|}{ Diet $^{1}$} & $\mathrm{SE}$ & $\frac{P \text {-value }}{\text { Treatment }}$ & \multicolumn{2}{|c|}{$P$-value (Contrast) } \\
\hline Mean pH & 6.44 & 6.39 & 6.36 & 6.37 & 0.07 & 0.776 & 0.346 & 0.708 \\
\hline Total VFA, mM & 122 & 123 & 130 & 125 & 3.14 & 0.309 & 0.335 & 0.322 \\
\hline Acetate, $\%$ of VFA & $62.17^{\mathrm{b}}$ & $64.26^{\mathrm{a}}$ & $63.85^{\mathrm{a}}$ & $63.82^{\mathrm{a}}$ & 1.08 & 0.023 & 0.003 & 0.488 \\
\hline Propionate, $\%$ of VFA & $20.70^{\mathrm{A}}$ & $19.90^{\mathrm{AB}}$ & $19.36^{\mathrm{B}}$ & $20.54^{\mathrm{A}}$ & 0.59 & 0.065 & 0.087 & 0.991 \\
\hline Valerate, $\%$ of VFA & 1.64 & 1.53 & 1.69 & 1.41 & 0.27 & 0.159 & 0.387 & 0.875 \\
\hline Iso-valerate, $\%$ of VFA & $1.52^{\mathrm{a}}$ & $1.28^{\mathrm{b}}$ & $1.38^{\mathrm{ab}}$ & $1.16^{\mathrm{b}}$ & 0.09 & 0.004 & 0.001 & 0.940 \\
\hline Caproate, $\%$ of VFA & $0.61^{\mathrm{b}}$ & $0.59^{\mathrm{b}}$ & $0.88^{\mathrm{a}}$ & $0.52^{\mathrm{b}}$ & 0.10 & 0.012 & 0.284 & 0.243 \\
\hline $\mathrm{BC}-\mathrm{VFA},{ }^{2} \%$ of VFA & $2.35^{\mathrm{a}}$ & $1.92^{\mathrm{b}}$ & $2.01^{\mathrm{b}}$ & $1.79^{\mathrm{b}}$ & 0.10 & $<0.001$ & $<0.001$ & 0.913 \\
\hline
\end{tabular}

${ }^{\mathrm{a}, \mathrm{b}}$ Different lowercase superscripts indicate a significant difference between treatments $(P<0.050)$.

${ }^{\mathrm{A}, \mathrm{B}}$ Different uppercase superscripts indicate a trend between treatments $(P<0.100)$.

${ }^{1} \mathrm{RW}=$ raw fava bean:linseed blend $\left(90: 10\right.$ raw basis); EXT $=$ extruded at $140^{\circ} \mathrm{C}$; $\mathrm{SUG}=$ extruded at $140^{\circ} \mathrm{C}$ after pretreatment with reducing sugars; $\mathrm{ENZ}=$ extruded at $140^{\circ} \mathrm{C}$ after pretreatment with an enzymatic cocktail.

${ }^{2}$ Branched-chain VFA, defined as the sum of iso-butyrate and iso-valerate.

\section{DISCUSSION}

Given the objectives of the present study, only results related to protein utilization will be discussed. It should, however, be noted that treatments had an effect on milk fat concentration (lower with EXT and SUG than with RW and ENZ). This was not observed by Mendowski et al. (2019), but in this previous study, milk fat concentrations were quite low with all treatments, including the control with soybean meal. To our knowledge, no other reference is available about milk response when dairy cows are fed extruded fava bean substituted for raw fava bean.

\section{N Partition and Productive Responses}

Despite measured difference in ED1, no difference was observed on $\mathrm{N}$ partition between raw and extruded blends, which is in disagreement with our initial hypothesis. In a previous study, Mendowski et al. (2019) similarly observed no significant difference in milk protein yield with extruded fava bean:linseed blends compared with raw ones. In both studies, the expected increase in PDI supply was counterbalanced by a decrease in PDI efficiency, in particular with the EXT diet. The decrease in PDI efficiency when PDI supply increases is classically observed (Subnel et al., 1994; Volden, 2011). The levels of PDI supply and their subsequent efficiency applied in the present study (respectively, $78 \mathrm{~g} / \mathrm{kg}$ of DM and $0.85 \mathrm{~g} / \mathrm{g}$ with RW, vs. 97 $\mathrm{g} / \mathrm{kg}$ of DM and $0.67 \mathrm{~g} / \mathrm{g}$ on average with EXT, SUG, and ENZ) would have led to a measurable response in milk protein yield (Sauvant et al., 2018). The lower net energy balance with SUG and ENZ may have attenuated the expected responses on milk protein yield
(Brun-Lafleur et al., 2010; Daniel et al., 2016). Also, the measured $\mathrm{N}$ balance (Table 6) was quite high and variable. This may impair detection of differences in $\mathrm{N}$ partition. Methodological limitations of $\mathrm{N}$ partition measurement in dairy cows have been previously described (Spanghero and Kowalski, 1997; Cutullic et al., 2013; Edouard et al., 2018). These authors underline that the $\mathrm{N}$ balance default (i.e., $\mathrm{N}$ balance minus $\mathrm{N}$ retention associated with growth, gestation, and positive energy balance) increases with $\mathrm{N}$ intake. In the present study, conducted on adult early-gestating cows, live BW changes of cows only slightly varied (less than + $90 \mathrm{~g} / \mathrm{d}$ ); assuming a retention of $33 \mathrm{~g}$ of protein/UFL balance (INRA, 2018), the $\mathrm{N}$ balance default averages (mean $\pm \mathrm{SD}) 65 \pm 39 \mathrm{~g} / \mathrm{d}$ (i.e., $9.7 \pm 5.7 \%$ of $\mathrm{N}$ intake). This is consistent with the average value of $8.4 \%$ of

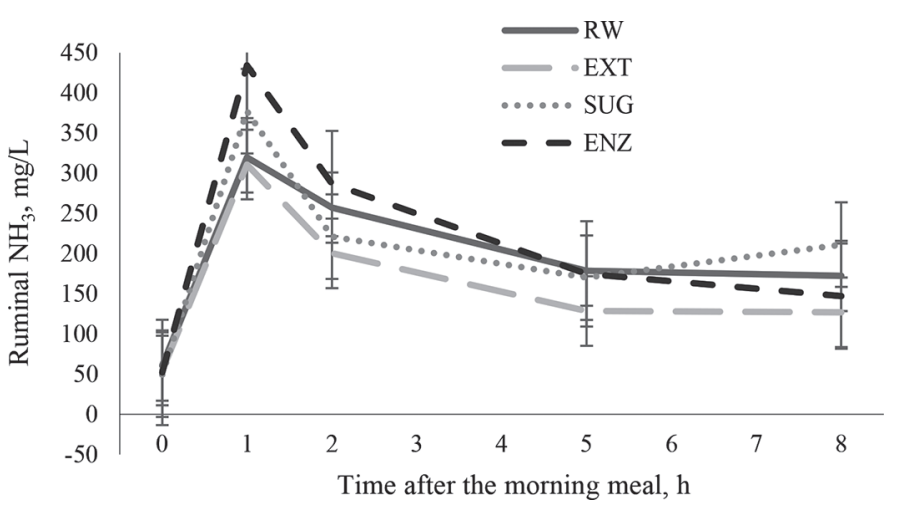

Figure 1. Effect of pretreatment before extrusion on postprandial variations in ruminal $\mathrm{NH}_{3}$ concentration. Vertical bars refer to $\mathrm{SE}$. $\mathrm{RW}$ = raw fava bean:linseed blend (90:10 raw basis); EXT = extruded at $140^{\circ} \mathrm{C} ; \mathrm{SUG}=$ extruded at $140^{\circ} \mathrm{C}$ after pretreatment with reducing sugars; $\mathrm{ENZ}=$ extruded at $140^{\circ} \mathrm{C}$ after pretreatment with an enzymatic cocktail. 
N intake reported by Spanghero and Kowalski (1997) with lower $\mathrm{N}$ intakes. The causes of $\mathrm{N}$ balance default may concern quantification in feed, milk, feces, urine, and even in sweat. In the present work, it varies according to cow $(P=0.042)$, period $(P<0.001)$, and diet $(P$ $=0.013)$, being higher with extruded treatments than with the raw one.

Although the overall treatment effect was not significant, a numerically higher $\mathrm{N}$ in milk/ $\mathrm{N}$ intake ratio was observed for SUG and ENZ compared with EXT (0.245 vs. 0.231). Although this supports numerically an advantage of pretreatment with additive before extrusion for $\mathrm{N}$ use efficiency, the differences remain low and are not supported by other indicators such as ruminal ammonia or plasma AA.

\section{Extrusion Conditions}

Published studies on the effects of extrusion of proteaginous seeds on milk production report highly variable results. This could partly be explained by the large diversity of extrusion processes used. Description of the characteristics of extrusion processes is scarce in the literature. The most common information given is the process duration, the target temperature, or more rarely the mechanical energy index.
In the present study, the duration of the process applied was similar to what is commonly used for extrusion (Kaysi and Melcion, 1992), and in particular for proteaginous seeds intended for ruminant diets (about 25-30 s, Benchaar et al., 1992; Petit et al., 1997; Froidmont et al., 2006). However, temperatures obtained in the present study as well as in our previous work (Mendowski et al., 2019) were lower than those reported by some others (up to $195^{\circ} \mathrm{C}$, Benchaar et al., 1991; Bayourthe et al., 1998) because only self-heating was used in our work. The temperature of $140^{\circ} \mathrm{C}$ is identical to that reported by Petit et al. (1997), who extruded pea without an external source of heat, and by Dovidaitiené et al. (2016).

For the same target temperature of $140^{\circ} \mathrm{C}$, and for an identical mechanical configuration, the extruders worked at $70 \%$ of their potential in the present study, versus $92 \%$ in the previous one. Outgoing parameters of extruders were also lower in the present study compared with the previous one: mechanical power averaged 80 versus $103 \mathrm{~kW}$; mechanical energy index was 56 (EXT), 55 (SUG), and 45 (ENZ, lower value due to addition of water) versus $60 \mathrm{Wh} / \mathrm{kg}$. This was consistent with the temperatures measured inside the extruders (on average $15^{\circ} \mathrm{C}$ lower in the present study than in the previous one). The mechanical energy index was lower for SUG

Table 9. Effect of protein source on plasma AA content and natural ${ }^{15} \mathrm{~N}$ enrichment $\left(\mathrm{n}_{\text {cows }}=8\right)$

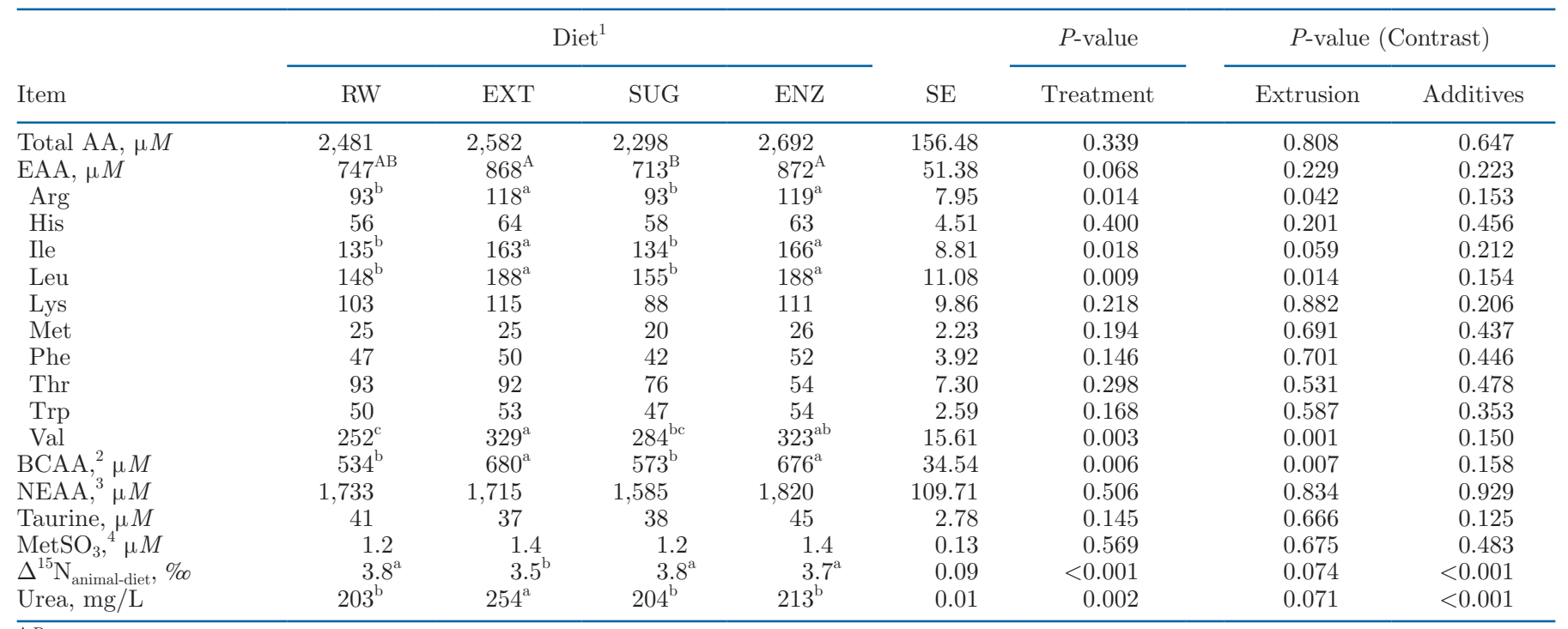

$\overline{\mathrm{A}, \mathrm{B}}$ Different uppercase superscripts indicate a trend between treatments $(P<0.100)$.

${ }^{\mathrm{a}-\mathrm{c}}$ Different lowercase superscripts indicate a significant difference between treatments $(P<0.050)$.

${ }^{1} \mathrm{RW}=$ raw fava bean:linseed blend $\left(90: 10\right.$ raw basis); EXT $=$ extruded at $140^{\circ} \mathrm{C} ; \mathrm{SUG}=$ extruded at $140^{\circ} \mathrm{C}$ after pretreatment with reducing sugars; $\mathrm{ENZ}=$ extruded at $140^{\circ} \mathrm{C}$ after pretreatment with an enzymatic cocktail.

${ }^{2}$ Branched-chain AA, defined as the sum of Ile, Leu, and Val.

${ }^{3} \mathrm{Ala}+\mathrm{Asn}+\mathrm{Asp}+\mathrm{Gln}+\mathrm{Glu}+\mathrm{Gly}+\mathrm{Pro}+\mathrm{Ser}+$ Tyr.

${ }^{4} \mathrm{MetSO}_{3}=$ methionine sulfoxide. 
than for EXT because, unlike mechanical power, it is inversely proportional to the flow of the matrix inside the extruder, and the flow was the highest for the SUG treatment.

As enzymes need a sufficient level of humidity to remain active, water was added during the extrusion process applied to the blend used in ENZ. Consequently, extrusion of this blend is not as strong as for the blends used in EXT and SUG. Indeed, water increased the fluidity of the fava bean-linseed matrix, and so increased the flow of this matrix through the extruder. This is illustrated by a higher ED1 for ENZ than for SUG and EXT (46 vs. $39 \%$ on average).

As shown by higher temperatures and a higher mechanical power, the treatment of extrusion was stronger for the SUG treatments than for the others, which is consistent with the trend for a lower total EAA content in plasma with SUG than with EXT and ENZ, suggesting an overprotection of proteins in the intestine.

\section{Protein Degradation}

When EXT is compared with RW, several results were consistent with our initial first hypothesis that proteins of extruded blend would be protected against degradation in the rumen compared with raw blend. This was confirmed by the lower ED1 (decrease from 82 to $39 \%$ of the blend used for EXT. Furthermore, it was supported by the numerically lower ruminal $\mathrm{NH}_{3}$ content (numerical decrease from 192 to $162 \mathrm{mg} / \mathrm{L}$ ), the significant decrease in branched-chain VFA (isobutyrate and iso-valerate, $P<0.001$ ) proportion in the rumen, the significant increase in branched-chain AA (Ile, Leu, and Val, $P=0.006$ ) plasma concentration, and the trend of higher plasma EAA concentration $(P=0.068$, Table 9$)$ with EXT than with RW. These results support the evidence of a lower degradation of proteins in the rumen (Nozière et al., 2010) and a subsequent higher availability of AA for the animals.

When SUG and ENZ are compared with EXT, several results were not consistent with our initial second hypothesis, which was that the use of additives during pretreatment would improve the protection of proteins in the rumen compared with pretreatment without additive. Indeed, ED1 was slightly higher (on average +7 $\mathrm{g} / 100 \mathrm{~g}$ ) for the blend used in ENZ than for both blends used in SUG and EXT. No difference was observed between EXT, SUG, and ENZ diets for ruminal branched VFA. Finally, more $\mathrm{NH}_{3}$ was observed in ruminal fluid with SUG and ENZ diets (+50 mg/L on average for both pretreatment with additives) than with EXT. This last result was unexpected, even if $\mathrm{NH}_{3}$ level in the rumen is not only strictly influenced by its produc- tion from dietary protein hydrolysis and deamination, but also depends on its use by microorganisms and on $\mathrm{NH}_{3}$ versus urea exchanges across the rumen wall and recycling through saliva.

The apparent digestibility of lysine was lower with SUG $(49.5 \%)$ than with the other diets $(57.0 \%$ on average). This may be due to a lower ruminal degradation or to a lower intestinal absorption. Considering the increase in ruminal $\mathrm{NH}_{3}$ contents, and the low lysine concentration in dietary CP (on average $4 \%$, Table 1) compared with the lysine contents in rumen microbe $\mathrm{CP}$ and duodenal endogenous CP (8.0 and 7.7\%, respectively, as retained in the PDI system by INRA, 2018), this may rather be related to a lower absorption in the intestine. This was also supported by the trend of lower total EAA content in plasma with SUG than with EXT and ENZ.

\section{Maillard Compounds}

Despite small differences in ED1 and similar results in rumen parameters (except caproate molar proportion), SUG and ENZ diets differed regarding the indicators of intestinal digestion (plasma EAA), which suggests a lower absorption of AA with SUG. This could partly be related to their respective and different contents in Maillard compounds. Furosine, which is not naturally present in seeds, is an early product of the Maillard reaction and appears during the first step of the Maillard reaction from protein or free AA. The CML is formed from lysine (one of the most sensitive AA to the Maillard reaction) and is a very stable terminal compound, which can be either free or bound to proteins. Acrylamide is also a terminal compound formed from free asparagine and glucose, and is not a protein-bound molecule.

The metabolism of Maillard compounds in ruminants is still poorly known; Mendowski et al. (2019) quantified Maillard compounds in ruminant digestibility studies, thus providing new information.

Extruded blends contained more CML than the raw blend and among the extruded blends, the highest CML content was observed in the blend used in SUG. This suggests that Maillard reactions increased with extrusion, in particular when sugars were added during pretreatment. Moreover, the blend used in SUG contained more acrylamide than the 3 other blends $(50.5 \times$ $10^{-6}$ vs. less than $32 \times 10^{-6} \mathrm{~g} / \mathrm{kg}$ of DM, respectively), confirming that more Maillard reactions happened with this treatment. Moreover, the blend used in SUG, and to a lesser extent in ENZ, contained a very high level of furosine compared with the blend used in RW, the blend used in EXT being intermediary. Contrary to 
CML and acrylamide, which are both terminal products of Maillard reactions, furosine is one of the early compounds. This suggests that the addition of reducing sugars, and to a lesser extent the addition of amylases during pretreatment, favors the start of Maillard reactions.

The CML contents in the extruded blends of the present study were higher than those observed in Mendowski et al. (2019) with extrusion at the same target temperature $\left(140^{\circ} \mathrm{C}\right)$, and even with extrusion at $160^{\circ} \mathrm{C}$. Given that this was unexpected and maybe related to inter-experiment variability, simultaneous measurements on blends from both studies (i.e., excluding a potential inter-experiment variability) were performed (data not shown). This indicates that CML contents in blends extruded at $140^{\circ} \mathrm{C}$ without additive during pretreatment were similar in both studies, and that addition of reducing sugars or amylases during pretreatment at $140^{\circ} \mathrm{C}$ led to $\mathrm{CML}$ levels similar to those with extrusion at $160^{\circ} \mathrm{C}$ without additive.

Apparent total-tract digestibility of CML was higher with ENZ (73\%), and to a lesser extent with EXT and SUG (averaging 71\%) compared with RW (64\%). The CML is known to be absorbable in the intestine (Tessier et al., 2012). Knowing the measured CML contents in blends and in the rest of the diet (i.e., in forages, beet pulp, and beet molasses), and the measured apparent digestibility of CML of the whole diet, the proportion of dietary CML provided by the blends can be calculated. Moreover, the digestibility of CML from the blends alone can be estimated by regression for each of the 8 "digestibility cows." The results indicate that the blend accounted for 13, 33, 41, and 40\% of CML provided in the whole diet for RW, EXT, SUG, and ENZ, respectively. They also show that digestibility of CML in blends was higher (on average 88\%) than that in the rest of the diet (60\%), and that digestibility of CML from blends alone $(88,89,85$, and $91 \%$ for blends used in RW, EXT, SUG, and ENZ treatments, respectively, $P=0.279$ ) was not significantly different. The same approach was applied to lysine, and the results showed that blends contributed a major part (71 to $78 \%$ ) of the dietary lysine supply, and that the apparent digestibility of lysine from blends alone did not differ between treatments $(85,89,86$, and $85 \%$ for blends used in RW, EXT, SUG, and ENZ treatments, respectively, $P=0.209$ ).

\section{Nitrogen Use Efficiency}

The $\Delta^{15} \mathrm{~N}_{\text {animal-diet}}$, which is the natural ${ }^{15} \mathrm{~N}$ enrichment of animal proteins over the diets, was expected to be negatively correlated with the $\mathrm{N}$ use efficiency (Cantalapiedra-Hijar et al., 2018). This has been ob- served in a preceding comparison between raw and extruded proteaginous seeds (Mendowski et al., 2019). In the present work, no significant overall relationship was observed between this biomarker and the $\mathrm{N}$ use efficiency. However, the range of variation in $\mathrm{N}$ use efficiency was rather low $(0.11 \mathrm{~g} / \mathrm{g}$ among the 32 measurements on the 8 "digestibility cows" and $0.14 \mathrm{~g} / \mathrm{g}$ among the 64 measurements on all 16 cows) compared with other published studies (up to $0.4 \mathrm{~g} / \mathrm{g}$, as reviewed by Cantalapiedra-Hijar et al., 2018), which may impair such evidence. However, $\Delta^{15} \mathrm{~N}_{\text {animal-diet }}$ was positively related to rumen $\mathrm{NH}_{3}$ concentration $\left(\mathrm{R}^{2}=0.52 ; P=0.008\right)$ as previously found in dairy cows (Cantalapiedra-Hijar et al., 2016), but unexpectedly was not related to PDI efficiency (Cantalapiedra-Hijar et al., 2018). This may suggest that variability in efficiency of $\mathrm{N}$ utilization was mainly related to digestive efficiency in this study conducted with animals having a relatively homogeneous potential in milk production. In a recent study in dairy cows, $\Delta^{15} \mathrm{~N}_{\text {animal-diet }}$ values decreased in animals fed tannin-treated grass silage compared with control without any change in $\mathrm{N}$ use efficiency (Herremans et al., 2019). However, in this study, a shift between fecal and urinary $\mathrm{N}$ was observed and authors concluded that $\Delta^{15} \mathrm{~N}_{\text {animal-diet }}$ would probably reflect the urinary $\mathrm{N}$ excretion rather than $\mathrm{N}$ use efficiency.

\section{CONCLUSIONS}

Several results, including Maillard compounds, ED1, rumen $\mathrm{NH}_{3}$, and plasma $\mathrm{AA}$, showed that extrusion of the fava bean:linseed blend without additive makes proteins less degradable in the rumen compared with the raw blend. Pretreatment with reducing sugars under the conditions described in this study led to a lower concentration of some plasma AA, suggesting an overprotection of proteins in the intestine. Pretreatment with amylases led to a similar level of AA in plasma as for the extruded blend without additive, suggesting that intestinal absorption of AA was comparable with both treatments. Despite the variations of $\mathrm{NH}_{3}$ concentration in ruminal fluid and plasma EAA concentration, no change in $\mathrm{N}$ partitioning was observed. These results altogether confirm that extrusion at $140^{\circ} \mathrm{C}$ is a promising way to improve the digestive utilization of proteins from fava bean by ruminants, and provide evidence that innovative processes such as adding reducing sugars or amylases during pretreatment before extrusion require more effort to achieve an optimal protection of proteins in the rumen and a good intestinal assimilation of proteins. More work is needed to potentiate the productive responses of the animals to those innovative treatments. 


\section{ACKNOWLEDGMENTS}

This study was conducted as part of the Proleval project, supported by Valorex (Combourtillé, France) and financed by bpifrance (Paris, France). The authors thank their colleagues at INRA: S. Rudel and the staff of "Les Cèdres": D. Roux, L. Mouly, V. Tate, G. De Falvard, J. Bourdassol, F. Rosa and J.-N. Beaufils (UE Herbipôle, Theix, France) for help with managing the experiment, sampling and animal care; V. Largeau, L. Genestoux, E. Tixier, I. Constant, P. Denis, C. Chantelauze, S. Nasrollahi (UMR Herbivores, Theix, France), O. Dhumez (UMR MoSAR, Paris, France), and T. Le Mouël (UMR Pegase, Rennes, France), for help with sampling and for their valuable technical support. The authors also thank C. Léridon (UniLaSalle, Beauvais, France) for her help with Maillard compound analyses. Finally, they thank D. Marsh (freelance editor, Courbevoie, France) for checking and amending the English text.

\section{REFERENCES}

Alamir, I., C. Niquet-Leridon, P. Jacolot, C. Rodriguez, M. Orosco, P. M. Anton, and F. J. Tessier. 2013. Digestibility of extruded proteins and metabolic transit of $\mathrm{N} \varepsilon$-carboxymethyllysine in rats. Amino Acids 44:1441-1449. https://doi.org/10.1007/s00726-012 $-1427-3$.

Aufrère, J., D. Graviou, C. Demarquilly, R. Vérité, B. MichaletDoreau, and P. Chapoutot. 1989. Aliments concentrés pour ruminants : prévision de la valeur azotée PDI à partir d'une méthode enzymatique standardisée. INRA Prod. Anim. 2:249-254.

Aufrère, J., D. Graviou, C. Demarquilly, R. Vérité, B. Michalet-Doreau, and P. Chapoutot. 1991. Predicting in situ degradability of feed proteins in the rumen by two laboratory methods (solubility and enzymatic degradation). Anim. Feed Sci. Technol. 33:97-116.

Bayourthe, C., R. Moncoulon, and F. Enjalbert. 1998. Effect of extruded lupin seeds as a protein source on lactational performance of dairy cows. Anim. Feed Sci. Technol. 72:121-131.

Bazin, S. 1984. Grille de notation de l'état d'engraissement des vaches Pie Noires. In Réseau national d'expérimentation et de démonstration en élevage bovin. S. Bazin, ed. Institut technique de l'élevage bovin, Paris, France.

Benchaar, C., C. Bayourthe, R. Moncoulon, and M. Vernay. 1991. Ruminal digestion and intestinal absorption of lupine proteins extruded in the lactating cow. Reprod. Nutr. Dev. 31:655-665.

Benchaar, C., M. Vernay, C. Bayourthe, and R. Moncoulon. 1992. Effet de l'extrusion de la féverole (Vicia faba) sur les flux intestinaux d'azote et d'amidon chez la vache laitière en production. Reprod. Nutr. Dev. 32:265-275.

Brun-Lafleur, L., L. Delaby, F. Husson, and P. Faverdin. 2010. Predicting energy $\times$ protein interaction on milk yield and milk composition in dairy cows. J. Dairy Sci. 93:4128-4143.

Cantalapiedra-Hijar, G., R. J. Dewhurst, L. Cheng, A. R. J. Cabrita, A. J. M. Fonseca, P. Nozière, D. Makowski, H. Fouillet, and I. Ortigues-Marty. 2018. Nitrogen isotopic fractionation as a biomarker for nitrogen use efficiency in ruminants: A meta-analysis. Animal 12:1827-1837.

Cantalapiedra-Hijar, G., I. Ortigues-Marty, A. M. Schiphorst, R. Robins, I. Tea, and S. Prache. 2016. Natural ${ }^{15} \mathrm{~N}$ abundance in key amino acids from lamb muscle: Exploring a new horizon in diet authentication and assessment of feed efficiency in ruminants. J. Agric. Food Chem. 64:4058-4067.
Chapoutot, P., O. Dhumez, G. Chesneau, A. Germain, S. Mendowski, and P. Nozière. 2018. Influence de l'extrusion sur la dégradabilité de l'azote de mélanges à base de féverole ou de lupin et effet de la distribution granulométrique des produits. Renc. Rech. Rum. 24:196.

Chapoutot, P., O. Dhumez, A. Germain, and G. Chesneau. 2016. Influence of extrusion on nitrogen degradability of faba bean or lupine blends including urea. Page 564 in Book of Abstracts of the 67th Annual Meeting of the European Federation of Animal Science, Belfast, UK. Wageningen Academic Publishers, Wageningen, the Netherlands.

Chapoutot, P., O. Martin, P. Nozière, and D. Sauvant. 2015. Systool Web, a new one-line application for the French INRA «Systali» project. Page 265 in Book of Abstracts of the 66th Annual Meeting of the European Federation of Animal Science, Warsaw, Poland. Wageningen Academic Publishers, Wageningen, the Netherlands.

Cros, P., M. Vernay, and R. Moncoulon. 1991. In situ evaluation of the ruminal and intestinal degradability of extruded whole horse beans. Reprod. Nutr. Dev. 31:249-255.

Cutullic, E., P. Faverdin, N. Edouard, and J. L. Peyraud. 2013. Report of simulation to quantify the effect of the main factors affecting $\mathrm{N}$ balance at cow level, Deliverable D7.3 of the Collaborative European Project FP7, Innovative and practical management approaches to reduce nitrogen excretion by ruminants (RedNex).

Daniel, J. B., N. C. Friggens, P. Chapoutot, H. Van Laar, and D. Sauvant. 2016. Milk yield and milk composition responses to change in predicted net energy and metabolizable protein: a meta-analysis. Animal 10:1975-1985.

DePeters, E. J., and J. P. Cant. 1992. Nutritional factors influencing the nitrogen composition of bovine milk: A review. J. Dairy Sci. 75:2043-2070.

Dovidaitienè, G., R. Gružauskas, R. Stankevičius, I. Monkevičienė, J. Kantautaite, I. Kudlinskiene, A. Grockiene, R. Želvytè, and J. Klementavičiūtè. 2016. Influence of extruded rapeseeds and faba beans mixture on productivity, production quality and rumen fluid parameters of dairy cows. Vet. Zootech. 79:20-26.

Duc, G., C. Mignolet, B. Carrouée, and C. Huyghe. 2010. Importance économique passé et présente des légumineuses: rôle historique dans les assolements et facteurs d'évolution. Innovations Agronomiques 11:1-24.

Edouard, N., A. Suzanne, P. Lamberton, B. Rouillé, and P. Faverdin. 2018. Complete nitrogen balance in dairy cows: Does every drop of sweat count? Xth International Symposium of Nutrition of Herbivores, Clermont-Ferrand, France.

Froidmont, E., M. Bonnet, Y. Beckers, and N. Bartiaux-Thill. 2006. Influence du degré de mouture et de l'extrusion sur la valeur nutritionnelle de la graine de lupin. Renc. Rech. Rum. 13:98.

Herremans, S., V. Decruyenaere, G. Cantalapiedra-Hijar, Y. Beckers, and E. Froidmont. 2019. Effects of hydrolysable tannin-treated grass silage on milk yield and composition, nitrogen partitioning and nitrogen isotopic discrimination in lactating dairy cows. Animal https://doi.org/10.1017/S175173111900226X.

INRA. 2018. INRA Feeding System for Ruminants. Wageningen Academic Publishers, Wageningen, the Netherlands.

INRA-CIRAD-AFZ Tables. 2017. Ingénierie \& Etudes. Accessed Mar. 14, 2018. https://feedtables.com/fr.

ISO. 2004. Animal feeding stuffs - enzymatic determination of total starch content. In: ISO-15914. International Organization for Standardization, Geneva, Switzerland.

Kaysi, Y., and J. P. Melcion. 1992. Traitements technologiques des protéagineux pour le monogastrique: Exemples d'application à la graine de féverole. Prod. Anim. 5:3-17.

Magrini, M.-B., M. Anton, C. Cholez, G. Corre-Hellou, G. Duc, M.-H. Jeuffroy, J.-M. Meynard, E. Pelzer, A.-S. Voisin, and S. Walrand. 2016. Why are grain-legumes rarely present in cropping systems despite their environmental and nutritional benefits? Analyzing lock-in in the French agrifood system. Ecol. Econ. 126:152-162.

Mendowski, S., P. Chapoutot, G. Chesneau, A. Ferlay, F. Enjalbert, G. Cantalapiedra-Hijar, A. Germain, and P. Nozière. 2019. Effects of replacing soybean meal by raw or extruded blends containing 
faba bean or lupin seeds on nitrogen metabolism and performances of dairy cows. J. Dairy Sci. 102:5130-5147.

Morgavi, D. P., H. Boudra, J. P. Jouany, and D. Graviou. 2003. Prevention of patulin toxicity on rumen microbial fermentation by $\mathrm{SH}-$ containing reducing agents. J. Agric. Food Chem. 51:6906-6910.

Niquet-Léridon, C., and F. Tessier. 2011. Quantification of $\mathrm{N} \varepsilon-$ carboxymethyl-lysine in selected chocolate-flavoured drink mixes using high-performance liquid chromatography-linear ion trap tandem mass spectrometry. Food Chem. 126:655-663.

Nozière, P., I. Ortigues-Marty, C. Loncke, and D. Sauvant. 2010. Carbohydrate quantitative digestion and absorption in ruminants: From feed starch and fibre to nutrients available for tissues. Animal 4:1057-1074.

Petit, H. V., R. Rioux, and D. R. Ouellet. 1997. Milk production and intake of lactating cows fed raw or extruded peas. J. Dairy Sci. 80:3377-3385.

Sauvant, D., G. Cantalapiedra-Hijar, S. Lemosquet, P. Nozière, V. Berthelot, and P. Faverdin. 2018. Protein and amino acids expenditure, efficiency and requirements. Pages 119-137 in INRA, 2018. INRA Feeding System for Ruminants. Wageningen Academic Publishers, Wageningen, the Netherlands.

Spanghero, M., and Z. M. Kowalski. 1997. Critical analysis of N balance experiments with lactating cows. Livest. Prod. Sci. 52:113122 .

Subnel, A. P. J., R. G. M. Meijer, W. M. Van Sraalen, and S. Tamminga. 1994. Efficiency of milk protein production in the DVE protein evaluation system. Livest. Prod. Sci. 40:215-224.
Terres Univia. 2017. Chiffres clés. Oléagineux et plantes riches en protéines.

Tessier, J., P. Jacolot, and C. Niquet-Léridon. 2012. La réaction de Maillard : cent ans de découvertes scientifiques sur la chimie des aliments et la santé. Lettre scientifique $\mathrm{n}^{\circ} 10$, Conférence du 22 novembre 2012. Fonds Français pour l'Alimentation et la Santé, Paris, France.

Titze, N., J. Krieg, H. Steingass, and M. Rodehutscord. 2019. Variation of lupin protein degradation in ruminants studied in situ and using chemical protein fractions. Animal 13:709-717.

Van Soest, P. J., J. B. Robertson, and B. A. Lewis. 1991. Methods of dietary fiber, neutral detergent fiber, and nonstarch polysaccharides in relation to animal nutrition. J. Dairy Sci. 74:3583-3597.

Volden, H. 2011. NorFor - The Nordic feed evaluation system. EAAP Publications No. 130, Wageningen Academic Publishers, Wageningen, the Netherlands.

Weatherburn, M. W. 1967. Phenol-hypochlorite reaction for determination of ammonia. Anal. Chem. 39:971-974

\section{ORCIDS}

A. Ferlay $\odot$ https://orcid.org/0000-0002-0651-792X

G. Cantalapiedra-Hijar () https://orcid.org/0000-0001-9486-8238

P. Nozière $\odot$ https://orcid.org/0000-0003-1727-8984 